\title{
Integrating World Cities into Production Networks: The Case of Port Cities
}

Published in: Global Networks 10(1), pp. 92-113 (2010)

Wouter Jacobs, Cesar Ducruet and Peter de Langen

W. Jacobs Erasmus School of Economics, Erasmus University Rotterdam, The Netherlands wjacobs@ese.eur.nl

C. Ducruet French National Centre for Scientific Research (CNRS), University of Paris-I Sorbonne, UMR 8504 Géographie-Cités,Paris, France

ducruet@parisgeo.cnrs.fr

P.W. de Langen Eindhoven University of Technology, Department of Industrial Engineering \& Innovation, The Netherlands, and Port of Rotterdam Authority

pw.langen@portofrotterdam.com

\begin{abstract}
This paper analyses the location patterns of firms that provide specialized advanced producer services (APS) to international commodity chains that move through seaports. Such activities can take place in world cities or in port cities. The analysis of APS location patterns in port cities provides a good opportunity to integrate the study of world cities into the framework of global production networks. Based upon our empirical findings, we conclude that while port-related APS activities predominantly follow the world city hierarchy, a number of port cities stand out because they act as nodes in global commodity flows and as centres of advanced services related to shipping and port activities. Based upon these empirical findings we address future avenues of research.
\end{abstract}

Keywords world city, global production network, port city, advanced producer services

Since the mid-1990s, a large body of research has emerged that deals with processes of economic-geographical globalization and the formation of global production networks, global value and commodity chains (Coe et al. 2004; Dicken et al. 2001; Ernst and Kim 2002; 
Gereffi and Korzenwiecz 1994; Gereffi et al. 2005; Henderson et al. 2002; Kaplinsky 2004). This research aims to conceptualize and understand the processes of industrial restructuring and the deregulation of national markets that has taken place since the late 1970s and resulted in a new spatial division of labour. Feenstra (1998: 31) summarizes this process as 'the integration of world trade and disintegration of production'.

During the same period, a different strand of research has emerged that focuses on the formation of world or global cities (Beaverstock et al. 2000; Knox and Taylor 1995; Sassen 1991; Taylor 1997, 2004). This research stream analyses how city hierarchies and urban systems are linked worldwide through corporate networks of advanced producer services (e.g. banks, insurance companies, and law firms) that control flows of capital and information. The focus is on how the dynamics of urban hierarchies is related to the overall restructuring of the world economy (Friedmann 1986). Both schools (hereafter referred to as GCC-GVC-GPN and $\mathrm{WCN}$ ) provide different but complementary analyses of the globalization of the economy. Few studies have attempted to conceptually and empirically integrate both bodies of research. Such integration seems necessary as it allows us to provide a more complete picture of the structure and evolution of the global economy. In this contribution to the special issue, we argue that port cities are an excellent area to empirically investigate the interaction between global commodity chains and advanced producer services.

This paper explores to what extent specific maritime and port-related advanced producer services are concentrated in world cities in general and in port cities in particular. Theoretically, the embeddedness of port cities in global networks needs further understanding. Interactions between (maritime) port activities that facilitate global commodity flows and other types of economic activities, most notably advanced producer services, are relevant to this area of research. Practically, port cities compete to attract port-related firms. Attracting APS may be a good strategy for port cities to upgrade their economies and strengthen the position of ports in a particular commodity chain.

The aims of this paper are twofold. First, we aim to integrate the respective conceptual frameworks of GCC-GVC-GPN and WCN. Second, we develop a method that allows us to empirically investigate the role and position of port cities in both global commodity chains and world city networks. This paper is structured as follows. In the next section, we look at the similarities and differences between GCC-GVC-GPN and WCN and discuss the role of port cities as a location where both advanced producer services and global commodity chains come together. We present an analytical framework and a research method in section three 
and our empirical results in section four. This paper ends with conclusions and future directions of port city research.

\section{Integrating World Cities and Global Production Networks}

Rather than providing a complete overview of the conceptual evolution of GCC-GVC-GPN and world city network research, we compare them conceptually and methodologically and address how an integrative approach could advance the study of the global economy (for a complete review, see Coe et al. 2008; Hess and Yeung 2006 on GCC-GVC-GPN; Brenner and Keil 2006; Derudder 2006 on WCN).

\section{World city networks and global production networks}

Both approaches analyse the dynamics and geography of the global economy. They start with the premise of a new globalized division of labour and industrial organization (cf. Fröbel et al. 1980), which resulted from a variety of factors such as changing economic policies ${ }^{1}$, and the cost reduction of new communication and transport technologies. This perspective draws inspiration from Castells' (1996) global transformation from a 'space of places' to a 'space of flows', although both approaches explicitly recognize that the world has become both (Derudder and Taylor 2005; Henderson et al. 2002; for a similar statement see Hesse, this issue).

Hence, although the concept of network is their core unit of analysis, the respective interests of the WCN school (i.e. international connectedness of cities through corporate networks), and of the GPN-school (i.e. territorial embeddedness of - social - networks involved in global commodities) remain somewhat different in nature and scope. The widely used WCN approach put forth by Sassen (1991) and Taylor (2004) looks at networks as the intra-firm links of advanced producer services in different locations. WCN does not take into account relations between these types of firms and other actors, nor does it pay attention to historical and institutional contexts that may partly explain interactions among firms and the structure of city networks. The GPN approach takes a more sophisticated and theoretical stand by emphasizing the relational character of networks (Dicken et al. 2001). Understanding networks as such requires the identification of different network actors, their social relationships and power configurations, as well as the structural outcomes of these interactions. 
As a result, the methodological approach differs. The WCN school draws on large datasets of location patterns of the world's leading advanced producer service providers. The GPN approach as mentioned by Hess and Yeung (2006) is essentially a heuristic approach with an underdeveloped methodological foundation (Dicken 2004). As a result, GPN research tends to be qualitative with a strong preference for interviews with key actors. As Hess and Yeung put it (2006: 1201), "it falls short of delivering a rigorous analysis that can give "the big picture" of GPNs on a global scale'. The WCN-approach provides the big picture on a global scale but often at the expense of a deeper understanding of the historical, institutional and strategic conditions that influence the formation development of cities and city networks. Nevertheless, we agree with them that research on GPNs should incorporate more explicitly quantitative data and relevant statistical tools into their analytical apparatus.

GCC-GVC-GPN is conceptually more comprehensive in scope than WCN. It is important to distinguish between GPN and GCC/GVC. According to Coe et al. (2008: 2), GCCs/GVCs are considered linear structures with sequential stages in the production-distribution-consumption chain through which value is added, whereas GPN 'strives to go beyond such linearity to incorporate all kinds of network configuration'. This implies that the GPN approach also includes non-linear linkages and social relationships (e.g. with state agencies or advanced producer services) that are active at different stages within the chain and that are not necessarily directly involved in the actual physical flow of the commodity at stake. Moreover, GPN is more comprehensive in the sets of actors and types of relationships it includes. GCC/GVC primarily focuses on the governance of inter-firm relationships, whereas GPN encompasses both intra- and inter-firm relationships and actors such as the state, NGOs, and international regulatory agencies. Furthermore, GPN pays attention to specific types of relationships (such as public private partnerships) or social network formations (e.g. business associations).

\section{Towards an integrated approach}

Recently, the WCN school has started to develop a relational approach. Beaverstock et al. (2002) see the formation of world city networks as the outcome of the interaction between two communities: territorial (city and state) and functional-economic (firm and sector). This approach explicitly recognizes the role and influence of sector-specific institutions, multiscalar governance arrangements and state-enforced regulations on the formation of interurban connections. As such, they have brought world city network analyses more in line with the GPN framework by including other actors as well as institutional and sector-specific 
features. More specifically, this contribution recognizes that cities are both embedded within networks (in this case of international operating advanced producer services) and within territorial contexts. Thus, despite little evidence about the specific role of APS within commodity chains and global production networks, the aforementioned studies have fostered integration between WCN and GPN frameworks towards a more accurate picture of the 'nexus of interconnected functions, operations and transactions through which a specific product or service is produced, distributed and consumed' (Coe et al. 2008: 2).

An important step to integrate WCN and GPN is acknowledging the non-linear relations that exist at certain places and at certain stages within the production chain (Coe et al. 2008). Conceptually, the GPN approach can incorporate linkages between producers, transporters and industrial suppliers on the one hand and advanced service providers on the other. Such an approach demands that we analyse the sector specificity of advanced producer services. ${ }^{2}$ In every production network, there is a need for advanced producer services (see also Brown et al, Lühti et al, this issue). Some provide specialized services for specific industries (e.g. maritime freight transport) or clusters of related industries (e.g. energy). Are these APS located in direct proximity of the nodes in the production chain, or do they arrange such transactions in proximity of other service activities located in 'world cities'?

Such an analysis can provide insights for strategic policy. The GPN approach argues that successful regional economic development depends to a large degree on strategic coupling (Coe et al. 2004), which refers to the capacity of local actors to couple critical regional assets with extra-local actors involved in global flows. The location of specialized APS in a region can accommodate insertion of local industries in global commodity chains.

\section{The case of port cities}

Despite their role in the worldwide distribution of goods (almost 90 per cent of world trade volumes are transported by ship), seaports have not received much attention in both bodies of research. Their position as transport hubs and production centres has been largely ignored by researchers on global commodity chains or production networks. ${ }^{3}$ On the other hand, WCN has largely ignored the significance of commodity flows and the role of APS in relation to these flows. However, attention to ports is relevant in WCN and GPN research for several reasons.

First, recent contributions in WCN have looked at the connectedness of world cities by investigating telecommunication, corporate networks (Rimmer 1999), airport traffic statistics (Derudder and Witlox 2005), and Internet connections (Choi et al. 2006). These contributions 
have looked at the importance of crucial physical infrastructure in the global transfer of both people and information as a proxy for world city connectedness. It is argued that inter-city linkages can be studied along the flows of people, information and commodity (Derudder and Taylor 2005; Smith and Timberlake 1995). The physical flow of commodities has been largely ignored by WCN-analysis. Further attention to seaports is relevant in this respect (see also Hesse this issue).

Second, ports are important transport nodes in the global supply chains of specific commodities in which value is created (Jacobs 2007; Robinson 2002; Wang et al. 2007) but have hardly been analysed from the GCC-GVC-GPN perspective. Qualitative case studies from Carbone and De Martino (2003) and Hall and Robbins (2007) have analysed the attempts of the ports of Le Havre (France) and Durban (South Africa) respectively, to become integrated with international automotive chains of Renault and Toyota, but conceptual studies are limited. Recent contributions (Jacobs and Hall 2007; Wang and Olivier 2006) have started to conceptually integrate ports with the work on global production networks and supply chains, but these studies are still in a premature phase.

Third, many ports have developed into a geographical concentration of related economic activities (cf. Langen 2003), including manufacturing facilities such as petro-chemical refineries, specialized suppliers of e.g. machine tools, maintenance firms, logistics service providers etc. In addition, many global commodity chains move through seaports: liquid bulk (e.g. oil and gas), dry bulk (e.g. ore and coal), food (grain, corn, soya, fruits) and other kinds of consumer goods shipped in containers. Ports are a good example of what Humphrey and Schmitz (2002: 1018) call 'export-oriented clusters that are inserted into global value chains', but have seldom been analysed. Fourth, WCN generally neglects the sector-specificity of advanced producer services. By focusing on port cities and port related activities, we can contribute to the development of $\mathrm{WCN}$ by focusing on advanced producer services specializing in the maritime and transport related industries. Our approach is summarized in Table 1.

\section{TABLE 1 ABOUT HERE}

\section{World Port City Networks: a framework for analysis}

The main activity of ports is enabling the transfer of goods from ships to other transport modes and vice versa. This generally requires temporary storage. Port-related activities such 
as wholesale, warehousing, logistics and transport are attracted to the direct proximity of ports due to reduced transaction and transport costs. In addition, some ports have also developed into major sites of production and manufacturing because of industries' dependency on the import of raw materials. For example, ports such as Rotterdam, Antwerp, Houston, and Singapore host extensive petro-chemical refineries and storage facilities. The concentration of industrial activity attracts utility and energy companies as well as other local suppliers of components and machinery.

The relationships between port and city changed considerably during the second half of the twentieth century (Levinson 2006). ${ }^{4}$ Ports have become increasingly disconnected from cities. Spatially, the increased intensity of port-industrial activity, in combination with urban growth, lack of available land for further expansion, and environmental constraints have led to the move of port facilities away from city centres (see Bird 1963; Hall 2007; Hoyle 1989). Institutionally, the devolution of local government control on the port's management (see Brooks and Cullinane 2007; Jacobs 2007) further eroded port-city relationships. Economically, this relationship resulted from reduced dependence of ports on the urban labour market as well as the reduced dependence of cities on ports for local economic growth. ${ }^{5}$

The degree to which port activities and advanced producer services (APS) are interdependent is unknown. While most evolutionary models depict stages of spatial and functional separation between port and urban activities (Ducruet and Lee 2006), there is a recognition of the less visible port-city relationship in the service sector (Amato 1999). The location pattern of APS tends to follow the urban hierarchy rather than the hierarchy of port throughputs, as seen in the cases of Canada (Slack 1989) and Australia (O'Connor 1989). O'Connor (1989) distinguishes three main types of locations: (1) port cities that provide basic services dealing with daily physical operations, (2) maritime industrial cities that manage long-term contracts and host more diverse functions (e.g. banking), and (3) international cities from where the global maritime shipping sector is managed. These studies, however, are not based on a sound empirical assessment of the extent to which maritime APS are located in port cities. Port economic impact studies rarely detail which activities among APS are influenced in their location by port functions.

The location of maritime APS is the result of two opposing forces. First, APS firms derive benefits from co-location with firms in port-industrial complexes, as physical proximity fosters the exchange of ideas and the building of trust. For example, an insurance company that specializes in marine terminals, vessels or storage facilities will have lower transaction 
costs and be able to closely monitor market demands if located in the port city. Second, APS located in a world city benefit from qualified labour as well as from relations with other APS firms. For instance, insurance products can be easily offered to port users from a world city at a distant location, with face-to-face contacts limited to occasional meetings in which representatives are flown in. For example, Lloyd's of London, the world's leading marketplace in maritime shipping insurances, forms the core of a highly spatially concentrated cluster in the City of London that facilitates international business relations in shipping, arbitration and insurance (Bennett 2001).

The extent to which port cities attract APS firms differs. Some ports are serviced completely by APS firms located elsewhere, while other port cities will attract more APS firms. Figure 1 shows our framework to empirically classify port cities in this respect. It shows the position of a port city in the world city hierarchy (in terms of specialized advanced producer services) on the horizontal axis and the volumes of commodities passing through the port on the vertical axis. Load centres are well positioned in GPN-GCC-GVCs because of heavy physical infrastructure, variety of transport (gateway) functions, regular shipping calls, large throughput volumes, and substantial market share within a given port range (Hayuth 1981; Notteboom 1997). Agglomeration economies remained limited due to geographical remoteness or to the lock-in effect of pre-existing urban centres (Fujita and Mori 1996). On the other hand, service centres have important ranks in the hierarchy of WCNs thanks to successful agglomeration economies, although the initial advantage of water transport is no longer dominant. For such places, functions related to the physical transfer of goods are often limited due to lack of space, congestion, environmental concerns, and the development of more sophisticated activities or central place functions.

In port cities and world port cities, urban and port functions coexist in relative harmony and interdependence. Port cities may attempt to evolve into load centres, service centres, or world port cities. On the one hand, general spatial processes related to the cyclical development of transport nodes, such as agglomeration or congestion, may be sufficient in some cases to explain the trajectory of port cities. On the other hand, specific territorial contexts, policies, and firm-specific factors and strategies may modify the general trend. For instance, following the collapse of the Socialist block in the early 1990s, important shipping line headquarters shifted from London to Hamburg (Ducruet 2006). 
Based on the World Shipping Register ${ }^{6}$ dataset, we map the location of the world's maritime advanced producer services. The choice of this database is motivated by its larger content and easier access compared with other maritime directories such as Lloyd's Maritime Directory or Fairplay's World Shipping Register. Among all activities included in the database presented in Appendix 1, the following port and transport related APS are discerned: insurance and law, consultancy and surveying, and maritime organizations. ${ }^{7}$ The database covering approximately 9,000 establishments of around 650 firms was refined by eliminating doublecounts and the few establishments without location information, resulting in a total of about 6,500 establishments. Although we recognize that this dataset is incomplete, we believe that it is a valid representation of the spatial distribution of specialized APS activity. For these APS firms, we have located their headquarters and counted the number of (inter) national links in the form of intra-firm networks for every port city. We then compare these data with the conventional list of world cities as developed by the Globalization and World Cities Research Network (GaWC) (see Beaverstock et al. 1999; Derudder and Taylor 2005; Taylor et al. 2009). However, we have decided not to make a ranking by assigning rather arbitrary scores as in earlier WCN contributions. Instead, we stick to a simple headquarters-subsidiary approach (Alderson and Beckfield 2004; Rozenblat and Pumain 2007).

Next, we link these data with port throughput figures as an indication of position within commodity chains. This information is publicly available through websites, annual reports and port statistics on a national level. However, we were unable to obtain information on the added value of the port throughputs. These data are only available in individual cases, and the definition and calculation method of added value greatly differs from one port to another. The precise location of APS and throughput was maintained whenever possible based on jurisdictional limits of the port area. For instance, Los Angeles and Long Beach remain apart, because they represent two different port jurisdictions. Although New York as a metropolis spreads across two different US states with marine terminals in New Jersey, there is only one port authority. By combining both data sources, we can see how port cities are positioned within the global flow of commodities and within the corporate networks of specialized advanced producer services.

\section{Empirical Results}

\section{The global picture of maritime and port-related APS}


When we look at the global picture of maritime related APS, one of the clearest findings is the dominant position of London. In terms of maritime law and insurance (see Figure 2), for example, London has twice as many establishments and headquarters than New York, the second city on the list. In addition, London is set apart in terms of international links, especially with Hong Kong, Singapore, New York and Tokyo. Much of London's central and dominant position can be explained by historical and institutional factors. Most international contracts between ship owners, insurance companies and third parties have been based upon English law ever since 'Britannia rule[d] the waves'. History might also explain the strong establishments and connectedness of former British crown colonies Hong Kong and Singapore. These port cities are intensively connected with London but do not share significant relations with each other or with the rest of Asia.

\section{FIGURE 2 ABOUT HERE}

The position of Asian world cities within the protection and indemnity (P\&I, marine insurance) and maritime law networks matches closely the conventional GaWC list (Taylor et al. 2009). As seen in Table 2, Singapore, Tokyo and Hong Kong are the leading cities in terms of APS in general as well as in this specific niche market. However, some cities that did not rank high in the GaWC research, such as Houston, Rotterdam, Panama City, Piraeus, Hamburg and Antwerp, clearly emerge as prime locations. This seems to prove the influence of a major seaport on the international connectedness of cities in terms of specialized advanced producer services. In the extreme cases of Panama City and Piraeus, this can be explained by the presence of crucial infrastructure or a flexible business environment for shipping (e.g. flag of convenience) in Panama and of a high concentration of ship owners in Piraeus. Our data also show the relatively strong position of some cities that do not have a seaport, such as Madrid, Moscow and Paris. This may be attributed to the dominance of the city in the national urban hierarchy and/or to centralist features of maritime related public administration.

\section{TABLE 2 ABOUT HERE}

Figure 3 presents the total picture of all maritime APS in our database (i.e. P\&I and law, consultants and surveyors, and maritime organizations). The graph represents the hierarchy of cities by a measure of betweenness centrality within the intra-firm networks, which is defined by the number of possible shortest paths running through every node in the graph. The position of cities in the graph thus echoes their respective proportion of exclusive linkages 
with other cities and their relative importance in terms of decision functions. For example, London hosts 71 headquarters that control 479 establishments in 350 different cities. Most of these cities are only connected to a London-based headquarter, as seen in the number of smaller dots forming the tributary gravitational area of London in Figure 3. With reference to the GaWC results, London can be said to be the world's maritime cluster nucleus.

\section{FIGURE 3 ABOUT HERE}

At the same time, other regional cores such as Houston, New York, Oslo, and Rotterdam also possess a dedicated network of subsidiaries while being strongly connected with London. Thus, the hierarchy of cities is closely related with the number of establishments under control. Compared with Figure 2, which is based on absolute scores, Singapore and Hong Kong are less important due to the fact that most of their establishments are controlled from external headquarters. Smaller cities such as Haugesund (Norway), St. Petersburg (Russia), and Gdansk (Poland) score better, because they act as subcluster nuclei in the Scandinavian and Baltic regions, respectively. Shanghai may have many connections with other leading APS centres in absolute terms, but in relative terms it acts as a regional location for foreignbased companies. The Chinese network gravitates around Beijing due to its role as political and administrative centre. Another important dimension in the graph is the closeness of some clusters that are in reality geographically distant from each other. In Figure 3 for instance, Haugesund is located in the vicinity of the Houston cluster, probably due to the focus on oil products. In the next section, we look at how the centres of specialized maritime advanced producer services perform in terms of the physical flows of commodities.

\section{Relation with Commodity Flows}

Total annual throughput volume per port (in metric tons) is used as measure of port activity. ${ }^{8}$ Total volume was preferred to container volume, because total tonnage includes the wide variety of cargoes introduced in Table 1, while containers remain a 'black box' of which the content of shipments is not known.

There is no straightforward relation between APS establishments and throughput tonnage (we do not observe noticeable correlations, cf. Table 3). While larger ports have generally more APS than smaller ports, cities with more APS do by no means have more cargo throughput. 
In order to plot port cities in the framework given in Figure 1, we standardize the data using zscores to compare the distributions. Figure 4 provides an overview of the position of port cities on the two dimensions and can be easily compared with the conceptual typology presented in Figure 1. Table 4 goes deeper in the analysis of regional and local variations in the European case.

\section{FIGURE 4 ABOUT HERE}

Figure 4 shows that there are only a few true world port cities, i.e. locations that are both leading nodes in commodity flows and centres of specialized maritime APS. The world port cities are Singapore, Rotterdam, Hong Kong, Hamburg, Houston, New York, Dubai, Tokyo, Antwerp and Shanghai. To a lesser extent, we can identify cities such as New Orleans, Vancouver, Amsterdam, Bremen-Bremerhaven, Los Angeles and Ho Chi Minh City. As mentioned, London is somewhat of a special case, since it dominates in APS establishments, but its port does not handle much traffic. The service centres are port cities that have strong positions within APS networks but not within the physical flows of goods. Some of these maritime centres do not have a port at all $^{9}$, most notably Mexico City DF, Madrid, Kuala Lumpur, Beijing, Taipei, Seoul and Moscow. Leading service centres are Piraeus, Panama City, Genoa, Istanbul, Limassol and Oslo. Some other service centres have a more balanced profile due to the larger throughput volumes: Southampton, Barcelona, Manila, Genoa, Gothenburg, and St. Petersburg.

Our data also clearly identifies load centres, i.e. port cities with a strong position in commodity flows but with a weak position in advanced producer services. One group is dominantly Asian. The Asian profile of the world's load centres is not a surprise, given the rise of manufacturing in China and Southeast Asia, resulting in tremendous traffic growth since the 1970s. Another explanation for why these port cities score weak on APS is evolutionary: they have only developed during the 1990s as growth poles with a strong dependency on established urban areas for advanced services. Load centres such as Ningbo (China), Chiba (Japan), and Shenzhen (China) may use APS located in service centres or in their respective world port cities of Shanghai, Tokyo, and Hong Kong.

Another type of load centre is composed of dedicated terminals near mining regions, such as in Australia (e.g. Dampier, Port Hedland) or Brazil (e.g. Tubarao, Itaqui) for exporting 
specific commodities. A third group are gateways to inland urban concentrations located at the head of mass freight corridors, such as Port Klang (Kuala Lumpur), Le Havre (Paris), and Santos (Sao Paulo). The final group consists of port cities that do not excel in advanced producer services or handle enormous traffic volumes. These port cities are often secondorder cities in their national urban system (e.g. Valencia, Liverpool, Trieste, and Constanta) that handle relatively limited cargo throughputs. In evolutionary terms, these port cities may have dropped down the hierarchy of cargo throughput and/or APS due to a variety of factors such as congestion, lack of space, and changing trade patterns, as seen in the cases of Liverpool and Baltimore.

A more detailed picture may be obtained from the comparison of rank in the APS hierarchy and distribution of commodity shares in total port traffic by port city (Table 4). Northern range port cities such as Rotterdam, Hamburg, and Antwerp rank high as locations of APS due to the presence of a strong port cluster embedding local and global industries with the port function. The higher share of roll on, roll off (ro-ro or automotive goods) traffic in some national capitals (e.g. Helsinki, Dublin, Piraeus, and Oslo) reflects the importance of passenger traffic and short-sea shipping rather than automotive chains. The specialization in container traffic shows the importance of the distribution and logistics function of some port cities such as Hamburg and Antwerp, which create value locally through warehousing and other ancillary services. The importance of container traffic in the south (e.g. Piraeus and Limassol) is better explained by transshipment activities that do not create much added value locally, because containers are simply shifted from one vessel to another across the terminal. These data suggest the absence of a direct relation between traffic specialization and rank in APS hierarchy. Ports exert various functions on different scales, responding to the need of the local, regional, and international economy. Commodity specialization illustrates only partially local industry specialization and insertion in particular value chains. Nevertheless, it is interesting to measure to what extent the activity of an entire port depends on a certain commodity, because traffic itself is a unique measure of the insertion of ports into global production networks.

\section{TABLE 4 ABOUT HERE}

\section{Conclusions}

Based upon our conceptual analysis, we developed a topology of locations that are firmly inserted in international physical commodity chains and serve as centres of specialized 
advanced producer services. It is clear that there is a weak relation between commodity flow patterns in ports and APS firm localization in port cities. This is probably because these two different activities, although they historically and spatially co-evolved within port cities, are fuelled by different logics. Specialized APS tend to agglomerate near other APS service providers along the (global) urban hierarchy instead of in the proximity of the commodity flows that move through ports. This is certainly the case for London and for other world cities such as New York, Singapore and Hong Kong. The concentration of maritime APS firms within non-port cities such as Madrid, Moscow and Paris supports this argument: these specialized APS agglomerate on the basis of something other than commodity flows, like proximity to political-administrative units, APS services in general or proximity to customers (e.g. headquarters of ship owners). This seems to suggest a spatial division of labour in which port-maritime advanced services are spatially disconnected from the global flow of commodities that it supports.

On the other hand, we can identify some specific cases such as Rotterdam, Houston and Hamburg where the concentration of physical flows coincides with the location of specialized APS functions, despite the relatively low ranking of these cities in conventional WCN rankings. This suggests co-location benefits of maritime APS with economic activities in global commodity chains. The development of the position of port cities in specialized APS networks is influenced by these opposing forces. This inconclusive statement calls for more empirical research in which the following methodological issues should be taken into account. We were not able, due to the lack of more detailed data on commodity-specific APS, to identify location patterns of APS specialised in a particular commodity chain. For example, the port cities of Rotterdam, Singapore and Houston have a dominant position within the commodity chains of crude oil and may thus be home to many APS specialised in oil/energy, In addition, we were unable to identify the urban economic impact of being a maritime APS centre. It remains the question how many jobs are generated by maritime APS within specific port cities or how much value is added by APS along the chain. However, our results indicate that some port cities attract more APS than predicted by their position in the WCN hierarchy. Further exploration of the influence of local port clusters on the international position of port cities within WCN and GPN hierarchies is needed. A third point of attention is the timefactor. In this study we have presented a static global picture, but it would be interesting to identify how certain patterns evolve over time. For example, the contemporary strong position 
of Dubai in terms of APS must be related to the emirate's rapid urban economic growth over the last two decades.

Future research should take into account these points of attention. Further studies that focus on a particular commodity and a specific local context should shed more light on the role of specialized advanced producer services within global production networks. This should be done by case-specific analysis in which both local APS and port-transport related activities are confronted with their degree of inter-firm interaction and the local spill-over that occurs in terms of employment, value creation and knowledge diffusion. It will also allow us to include specific institutional features into the analysis as well as to assess the role of strategic policy and government agencies in shaping the development paths of port cities in the global economy. Some methodological issues may be addressed, such as an analysis based on morphological and/or functional criteria defining port cities based on port jurisdictions or functional economic areas. Traffic data in this study should be complemented with container traffic, as it constitutes the most valuable cargo passing through seaports. In addition, research may benefit from further application of social network analysis through graph visualization and the use of clustering techniques to highlight the cliquishness of port cities within geographical and/or functional regions of the world.

\section{Acknowledgements}

The authors would like to thank Hans Koster for his contribution to data collection and cartography. The authors are thankful for the insightful comments by three anonymous reviewers. An earlier draft of this manuscript had been made available as Research Bulletin 298 on the Globalization and World Cities Research Network (GaWC) website. The usual caveats apply.

\section{Notes}

1 We recognize that both schools have drawn inspiration from works that date back farther. In the case of WCN, reference is often made to Geddes (1924) and Hall (1966), who have used the term 'world city' in a different historical context. In the case of GPN, much inspiration is drawn from Granovetter (1985) on the 'social embeddedness' of rational economic behavior. Here, we primarily refer to Castells (1996) as a shared source to summarize the importance of 
'networks', both in the metaphorical and material sense, that underpin the economic geography of the global economy and its conceptualizations (see Dicken et al. 2001).

2 Note that our approach to the sector-specificity of APS firms differs from that of Beaverstock et al. (2002). Our focus is on the inter-sectoral specialization of APS (e.g. the insurance of ships instead of real estate) as opposed to the specific structure of certain sectors where certain APS activities take place (e.g. the insurance sector). Our approach is more in line with that of Jane Jacobs (1969).

3 As mentioned by Coe et al. (2008: 6): 'In fact, with the vastly increased complexity and geographical extensiveness of production networks ... the logistics problem is absolutely central. We need to understand it. And, yet it is virtually ignored outside the specialist technical world of supply chain management.'

4 Port cities are historically commercial centers with considerable geo-economic and political power. During the 1600s, a banking system emerged in cities such as Venice, Amsterdam and London around the commodity trade through these seaports (O'Connor 1989). Over the last two centuries the location of these financial and trade-related economic activities has become more dispersed.

5 Port regions often struggle to upgrade and diversify their economy. Recent studies confirm that industrial port regions underperform in terms of traffic growth compared with port regions where the service sector is relatively strong (Ducruet 2009). Furthermore, de Langen (2007) shows that the growth of cargo volumes in US ports does not automatically lead to good regional economic performance (see also Grobar 2008).

6 Available at http://e-ships.net/., accessed between May and September 2008.

7 WCN usually also discern other types of APS such as ICT, banking, marketing and accountancy. We have not included these types in our study for two reasons. First, we believe that there is limited sector-specific specialization among these types of APS. Second, these types are not included in the World Shipping Register database.

8 Data were extracted from Eurostat, the Association of American Port Authorities, and from various port authorities' websites.

9 The traffic of these inland cities was counted as zero. 


\section{References}

Amato, D. (1999) 'Port planning and port/city relations', The Dock and Harbor Authority, July-December, 45-48.

Alderson, A.S. and J. Beckfield (2004) 'Power and position in the world city system', American Journal of Sociology, 109, 811-51.

Beaverstock, J.V., P. J. Taylor, and R.G. Smith (1999) 'A roster of world cities', Cities, 16(6), 445-58.

Beaverstock, J. V, R. G. Smith, and P. J. Taylor (2000) 'World City Network: a new metageography?', Annals of the Association of American Geographers, 90(1), 123-34.

Beaverstock, J.V., M. A. Doel, P. J. Hubbard, and P.J. Taylor (2002) 'Attending to the world: competition, cooperation and connectivity in the World City Network', Global Networks, 2(2), 111-32.

Bird, J. (1963) The major seaports of the United Kingdom, London: Hutchinson.

Bennett, P. (2001) 'Mutual risk: P\&I insurance clubs and maritime safety and environmental performance', Marine Policy, 25(1), 13-21.

Brenner, N. and R. Keil (eds) (2006) The global cities reader. London: Routledge.

Brooks, M. and K. Cullinane (eds) (2007) Devolution, port governance and performance, Dordrecht: Elsevier.

Carbone, V. and M. De Martino (2003) 'The changing role of ports in supply-chain management: an empirical analysis', Maritime Policy and Management, 30(4), 305-320.

Castells, M. (1996) The rise of the network society. The information age: economy, society and culture, Oxford: Blackwell.

Coe, N.M., P. Dicken and M. Hess (2008) 'Global production networks: realizing the potential', Journal of Economic Geography, 8(3), 271-295. 
Coe, N. M., M. Hess, H. W-C. Yeung, P. Dicken, and J. Henderson (2004), 'Globalizing regional development: a global networks perspective', Transactions of the Institute of British Geographers, 29, 468-84.

Choi, J.H., G. A. Barnett, and B.S. Chon (2006) 'Comparing world city networks: a network analysis of Internet backbone and air transport intercity linkages', Global Networks, 6(1), 8199.

Derudder, B. (2006) 'On conceptual confusion in empirical analyses of a transnational network', Urban Studies, 43 (11), 2027-46.

Derudder, B. and F. Witlox (2005) 'An appraisal of the use of airline data in assessing the World City Network: A research note on data', Urban Studies, 42(13), 2371-88.

Derudder, B. and P.J. Taylor (2005) 'The cliquishness of world cities', Global Networks, 5(1) 71-91.

Dicken, P. (2004) 'Geographers and globalization: (yet) another missed boat?', Transactions of the Institute of British Geographers, 29(5), 5-26.

Dicken, P., P. F. Kelly, K. Olds, and H. W-C. Yeung (2001) 'Chains and networks, territories and scales: towards a relational framework for analysing the global economy', Global Networks, 1(2), 89-112.

Ducruet, C. (2006) 'Port-city relationships in Europe and Asia', Journal of International Logistics and Trade, 4(1), 13-35.

Ducruet, C. (2009) 'Port regions and globalization', in T. E. Notteboom, C. Ducruet, and P. W. De Langen (eds) Ports in proximity: competition and cooperation among adjacent seaports, Aldershot, Ashgate (in press).

Ducruet, C. and S.W. Lee (2006) 'Frontline soldiers of globalization: port-city evolution and regional competition', GeoJournal, 67(2), 107-22.

Ernst, D. and L. Kim (2002) 'Global production networks, knowledge diffusion and local capability formation', Research Policy, 31(8/9), 1417-29.

Feenstra, R.C. (1998) 'Integration of trade and disintegration of production in the global economy', Journal of Economic Perspectives, 12(4), 31-50. 
Friedmann, J. (1986) 'The world city hypothesis', Development and Change, 17(1), 69-83.

Fröbel, F., J. Heinrichs, and O. Kreye (1980) The new international division of labour, Cambridge: Cambridge University Press.

Fujita, M. and T. Mori (1996) 'The role of ports in the making of major cities: selfagglomeration and hub-effect', Journal of Development Economics, 49(1), 93-120.

Geddes, P. (1924) ‘A world league of cities', Sociological Review, 26, 166-67.

Gereffi, G., J. Humphrey and T. Sturgeon (2005) 'The governance of global value chains', Review of International Political Economy, 12(1), 78-104.

Gereffi, G. and M. Korzeniewicz (eds) (1994) Commodity chains and global capitalism, Westport: Praeger.

Grobar, L.M. (2008) 'The economic status of areas surrounding major U.S. container ports: evidence and policy issues', Growth and Change, 39(3), 497-516.

Granovetter, M. (1985) 'Economic action and social structure: the problem of embeddedness' American Journal of Sociology, 91(3), 481-510.

Hall, P. (1966) The world cities, London: Heinemann.

Hall, P.V. (2007), Seaport, urban sustainability and paradigm shift, Journal of Urban Technology, 12, 87-101.

Hall, P.V. and G. Robbins (2007) 'Which link in which chain? Inserting Durban into global automotive chains', in J.J. Wang, D. Olivier, T.E. Notteboom and B. Slack (eds) Inserting port cities in global supply chains, Aldershot: Ashgate, 221-31.

Hayuth, Y. (1981) 'Containerisation and the load centre concept', Economic Geography, 57(2), 160-176.

Henderson, J., P. Dicken, N. M. Coe, and H.W-C. Yeung (2002) 'Global production networks and the analysis of economic development', Review of International Political Economy, 9(3), 436-64.

Hess, M. and H.W-C. Yeung (2006) 'Whither global production networks in economic geography? Past, present and future', Guest editorial, Theme Issue on Global Production 
Networks, Environment and Planning A, 38(7), 1193-1204.

Hoyle, B.S. (1989) 'The port-city interface: Trends, problems and examples', Geoforum, 20(4), 429-35.

Humphrey, J. and H. Schmitz (2002) 'How does insertion in global value chains affect upgrading in industrial clusters?', Regional Studies, 36(9), 1017-27.

Jacobs, J. (1969) The economy of cities, New York: Vintage.

Jacobs, W. (2007) Political economy of port competition: institutional analyses of Rotterdam, Southern California and Dubai, Nijmegen: Academic Press Europe.

Jacobs, W. and P.V. Hall (2007) 'What conditions supply chain strategies of ports? The case of Dubai', GeoJournal, 68(4), 327-42.

Kaplinsky, R. (2004) 'Spreading the gains from globalization. What can be learned from value-chain analysis?', Problems of Economic Transition, 47(2), 74-115.

Knox, P. and P.J. Taylor (eds) (1995) World cities in a world system, Cambridge: Cambridge University Press.

Langen, P.W. de (2003) The performance of seaport clusters, Rotterdam: ERIM.

Langen, P.W. de (2007) 'The economic performance of seaport regions', in J.J. Wang, D.

Olivier, T.E. Notteboom and B. Slack (eds) Ports, cities and global supply chains, Aldershot: Ashgate, 187-202.

Levinson, M. (2006) The box: how the shipping container made the world smaller and the world economy bigger, Princeton: Princeton University Press.

Notteboom, T.E. (1997) 'Concentration and the load center development in the European container port system', Journal of Transport Geography, 5(2), 99-115.

O’Connor, K. (1989) ‘Australian ports, metropolitan areas and trade-related services', The Australian Geographer, 20(2), 167-72.

Rimmer, P.J. (1999) 'The Asia-Pacific Rim's transport and telecommunications systems: spatial structure and corporate control since the mid-1980s', Geojournal, 48(1), 43-65. 
Robinson, R. (2002) 'Ports as elements in value-driven chain systems: the new paradigm', Maritime Policy and Management, 29(3), 241-55.

Rozenblat, C. and D. Pumain (2007), Firm linkages, innovation and the evolution of urban systems, in P. J.Taylor, B. Derudder, P. Saey, and F. Witlox (eds) Cities in Globalization. Practices, policies and theories, London: Routledge, 130-56.

Sassen, S. (1991) The global city: New York, London, Tokyo. Princeton: Princeton University Press.

Smith, D.A. and M. Timberlake (1995) 'Cities in global matrices: toward mapping the worldsystems' city system', in P.L. Knox and P.J. Taylor (eds) World cities in a world-system, Cambridge: Cambridge University Press, 79-97.

Slack, B. (1989) 'Port services, ports and the urban hierarchy', Tijdschrift voor Economische en Sociale Geografie, 80(4), 236-243.

Taylor, P.J. (1997) 'Hierarchical tendencies amongst world cities: a global research proposal', Cities, 14(6), 323-32.

Taylor, P.J. (2004) World city networks: A global urban analysis, London: Routledge.

Taylor, P.J., P. Ni, B. Derudder, M. Hoyler, J. Huang, F. Lu, K. Pain, F. Witlox, X. Yang, D. Bassens, and W. Shen (2009) 'Measuring the World City Network: new developments and results', GaWC Research Bulletin 300.

Wang, J.J. and D. Olivier (2006) 'Port-FEZ bundles as spaces of global articulation: the case of Tianjin, China', Environment and Planning A, 38(8), 1487-1503.

Wang, J.J., D. Olivier, T. Notteboom, and B. Slack (eds) (2007) Ports, cities and global supply chains, Aldershot: Ashgate. 
Table 1: World Port-City Network Analysis

\begin{tabular}{|c|c|c|}
\hline Ports & Research focus & Cities \\
\hline GCC-GVC-GPN & Conceptual & World City Networks \\
\hline $\begin{array}{l}\text { Intra and Inter firm Network of } \\
\text { Producers and Suppliers }\end{array}$ & Unit of Analysis & $\begin{array}{l}\text { Intra Firm Network of Advanced } \\
\text { Producer Services }\end{array}$ \\
\hline $\begin{array}{l}\text { Specialized Manufacturing } \\
\text { Stevedoring } \\
\text { Wholesale \& Trade } \\
\text { Transport } \\
\text { Logistics \& Warehousing } \\
\text { Offshore }\end{array}$ & Types of Activities / Sectors & $\begin{array}{l}\text { Financial Services } \\
\text { Insurance } \\
\text { Legal Services } \\
\text { Consultancy-R\&D } \\
\text { Engineering } \\
\text { ICT }\end{array}$ \\
\hline $\begin{array}{l}\text { Containers } \\
\text { Liquid Bulk (crude oil, LNG, } \\
\text { chemicals) } \\
\text { Agri-Bulk (grain, corn, soya, fruits) } \\
\text { Break bulk (ore, coal, scrap) } \\
\text { RoRo (automotive) } \\
\text { General cargo (forestry, iron, steel } \\
\text { products) }\end{array}$ & Specialization & $\begin{array}{l}\text { Merchant Banking } \\
\text { Ship Finance } \\
\text { Maritime Insurance \& Brokerage } \\
\text { (Hull, P\&l, Charterers Liability) } \\
\text { Maritime Law \& Arbitration } \\
\text { Maritime Education \& Research } \\
\text { Software }\end{array}$ \\
\hline $\begin{array}{l}\text { Throughputs } \\
\text { Added Value } \\
\text { Employment }\end{array}$ & Variables & $\begin{array}{l}\text { Urban Size } \\
\text { Office Locations } \\
\text { Land rents, wage levels } \\
\end{array}$ \\
\hline
\end{tabular}

Table 2: Ranking of World Cities according the GaWC (2008) compared with Port-City APS.

\begin{tabular}{|c|c|c|c|c|}
\hline $\begin{array}{l}\text { The GaWC } \\
\text { ranking of World } \\
\text { Cities } 2008 \\
\text { (Taylor et al 2009) }\end{array}$ & $\begin{array}{l}\text { The ranking of } \\
\text { port related APS } \\
\text { cities }\end{array}$ & $\begin{array}{l}\text { World Cities of GaWC } \\
\text { not included in Top } \\
40 \text { Port related APS } \\
\text { city ranking }\end{array}$ & $\begin{array}{l}\text { Port related APS } \\
\text { cities not included in } \\
\text { Top } 40 \text { world cities } \\
\text { GaWC ranking } 2008\end{array}$ & Overlap \\
\hline$A L P H A++$ & London & Milan & Piraeus & London \\
\hline London & Singapore & Warsaw & Rotterdam & New York \\
\hline New York & Piraeus & Budapest & Hamburg & Tokyo \\
\hline$A L P H A+$ & New York & Zurich & Antwerp & Singapore \\
\hline Hong Kong & Rotterdam & Toronto & Genoa & Shanghai \\
\hline Paris & Hong Kong & Chicago & Houston & Hong Kong \\
\hline Singapore & Hamburg & Sao Paulo & Dubai & Paris \\
\hline Sydney & Panama City & Vienna & Panama City & Madrid \\
\hline Tokyo & Houston & Caracas & Oslo & Brussels \\
\hline Shanghai & Tokyo & Prague & Limassol & Washington \\
\hline Beijing & Dubai & Amsterdam & New Orleans & Buenos Aires \\
\hline$A L P H A$ & Shanghai & Santiago & Valetta & Sydney \\
\hline Milan & Antwerp & Rome & Alexandria & Istanbul \\
\hline Madrid & Madrid & Taipei & Vancouver & Jakarta \\
\hline Seoul & Mumbai & Dublin & Seattle & Auckland \\
\hline Moscow & Limassol & Lisbon & Durban & Athens \\
\hline Brussels & Oslo & Beijing & Cape Town & Miami \\
\hline Toronto & Paris & Kuala Lumpur & Rio de Janeiro & Seoul \\
\hline Mumbai & New Orleans & Stockholm & Manila & Mumbai \\
\hline Buenos Aires & Istanbul & Mexico City & & Bangkok \\
\hline Kuala Lumpur & Genoa & Frankfurt & & Moscow \\
\hline ALPHA - & Sydney & & & \\
\hline Warsaw & Miami & & & \\
\hline Jakarta & Moscow & & & \\
\hline
\end{tabular}




\begin{tabular}{|l|l|}
\hline Sao Paulo & Washington \\
\hline Zurich & Buenos Aires \\
\hline Mexico City & Valletta \\
\hline Dublin & Seoul \\
\hline Amsterdam & Jakarta \\
\hline Bangkok & Alexandria \\
\hline Taipei & Brussels \\
\hline Rome & Rio de Janeiro \\
\hline Istanbul & Athens \\
\hline Lisbon & Cape Town \\
\hline Chicago & Vancouver \\
\hline Frankfurt & Seattle \\
\hline Stockholm & Manila \\
\hline Vienna & Bangkok \\
\hline Budapest & Durban \\
\hline Athens & Auckland \\
\hline Prague & \\
\cline { 1 - 1 } Caracas & \\
\cline { 1 - 1 } Auckland & \\
\hline Santiago & \\
\cline { 1 - 1 } &
\end{tabular}

Table 3: Correlations between maritime APS and port tonnage

\begin{tabular}{|c|c|c|c|c|}
\hline Method & \multicolumn{2}{|c|}{ Throughput ranking } & \multicolumn{2}{|c|}{ APS ranking } \\
\hline \multirow{5}{*}{$\begin{array}{l}\text { RAW } \\
\text { DATA }\end{array}$} & Top 10 ports & 0.431 & Top 10 APS & -0.077 \\
\hline & Top 20 ports & 0.310 & Top 20 APS & 0.129 \\
\hline & Top 30 ports & 0.308 & Top 30 APS & 0.266 \\
\hline & Top 50 ports & 0.444 & Top 50 APS & 0.367 \\
\hline & All ports & 0.309 & All APS & 0.299 \\
\hline \multirow{5}{*}{$\begin{array}{c}\text { LOG } \\
\text { DATA }\end{array}$} & Top 10 ports & 0.288 & Top 10 APS & 0.053 \\
\hline & Top 20 ports & 0.150 & Top 20 APS & 0.263 \\
\hline & Top 30 ports & 0.278 & Top 30 APS & 0.359 \\
\hline & Top 50 ports & 0.158 & Top 50 APS & 0.336 \\
\hline & All ports & 0.304 & All APS & -0.113 \\
\hline
\end{tabular}


Table 4: Commodity traffic at main APS concentrations in Europe

Source: realized by authors based on Eurostat (2008) and port authorities' websites

* Traffic shares for Istanbul are calculated based on quay length due to lack of data

\begin{tabular}{|c|c|c|c|c|c|c|c|c|c|}
\hline \multirow[b]{2}{*}{ Rank } & \multirow[b]{2}{*}{ City } & \multicolumn{2}{|c|}{$\begin{array}{l}\text { Advanced Producer } \\
\text { Services (APS) }\end{array}$} & \multicolumn{6}{|c|}{ Port traffic (2006) } \\
\hline & & $\begin{array}{l}\text { No. } \\
\text { Establ. }\end{array}$ & No. HQs & $\begin{array}{l}\text { Total } \\
(000 \\
\text { tons }) \\
\end{array}$ & $\begin{array}{c}\text { Solid } \\
\text { bulk (\%) }\end{array}$ & $\begin{array}{l}\text { Liquid } \\
\text { bulk (\%) }\end{array}$ & $\begin{array}{c}\text { General } \\
\text { cargo } \\
(\%)\end{array}$ & $\begin{array}{l}\text { Ro-ro } \\
(\%)\end{array}$ & $\begin{array}{c}\text { Containers } \\
(\%)\end{array}$ \\
\hline 1 & London & 386 & 71 & 51,911 & 26.6 & 36.8 & 7.2 & 17.4 & 12.0 \\
\hline 2 & Piraeus & 187 & 14 & 19,959 & 1.9 & 1.3 & 0.4 & 26.9 & 69.5 \\
\hline 3 & Rotterdam & 128 & 10 & 353,576 & 24.2 & 49.0 & 2.8 & 3.0 & 20.9 \\
\hline 4 & Hamburg & 97 & 8 & 115,529 & 24.9 & 12.3 & 2.0 & 0.3 & 60.5 \\
\hline 5 & Antwerp & 68 & 2 & 151,704 & 16.9 & 24.9 & 12.0 & 3.6 & 42.6 \\
\hline 6 & Madrid & 60 & 7 & - & - & - & - & - & - \\
\hline 7 & Limassol & 56 & 8 & 3,533 & 11.1 & 0.0 & 12.1 & 7.4 & 69.3 \\
\hline 8 & Oslo & 55 & 8 & 6,410 & 26.7 & 31.9 & 5.3 & 19.9 & 16.3 \\
\hline 9 & Paris & 55 & 6 & 22,256 & 81.1 & 2.9 & 11.5 & 0.6 & 3.8 \\
\hline 10 & |stanbul* & 53 & 5 & 7,834 & 6.3 & 0.0 & 49.8 & 11.8 & 27.7 \\
\hline 11 & Genoa & 53 & 3 & 40,619 & 6.8 & 45.7 & 3.3 & 15.3 & 28.9 \\
\hline 12 & Moscow & 49 & 5 & - & - & - & - & - & - \\
\hline 13 & Valletta & 47 & 0 & 1,992 & 27.7 & 48.8 & 6.4 & 11.1 & 5.7 \\
\hline 14 & Brussels & 41 & 0 & 4,200 & 52.8 & 28.8 & 15.5 & 0.0 & 2.8 \\
\hline 15 & Copenhagen & 35 & 4 & 6,896 & 33.7 & 43.0 & 2.5 & 5.8 & 15.0 \\
\hline 16 & Southampton & 35 & 2 & 40,557 & 5.6 & 69.6 & 0.3 & 3.8 & 20.6 \\
\hline 17 & Helsinki & 35 & 0 & 11,669 & 8.9 & 3.8 & 7.5 & 48.1 & 31.7 \\
\hline 18 & Odessa & 34 & 2 & 28,009 & 0.2 & 46.1 & 40.1 & 0.6 & 13.2 \\
\hline 19 & Dublin & 34 & 1 & 20,796 & 9.9 & 19.5 & 1.5 & 43.0 & 26.0 \\
\hline 20 & Gothenburg & 32 & 2 & 39,912 & 0.6 & 52.5 & 0.2 & 30.1 & 16.6 \\
\hline
\end{tabular}


Figure 1: Analytical framework and port city typology. Source: realized by authors based on Ducruet and Lee (2006)

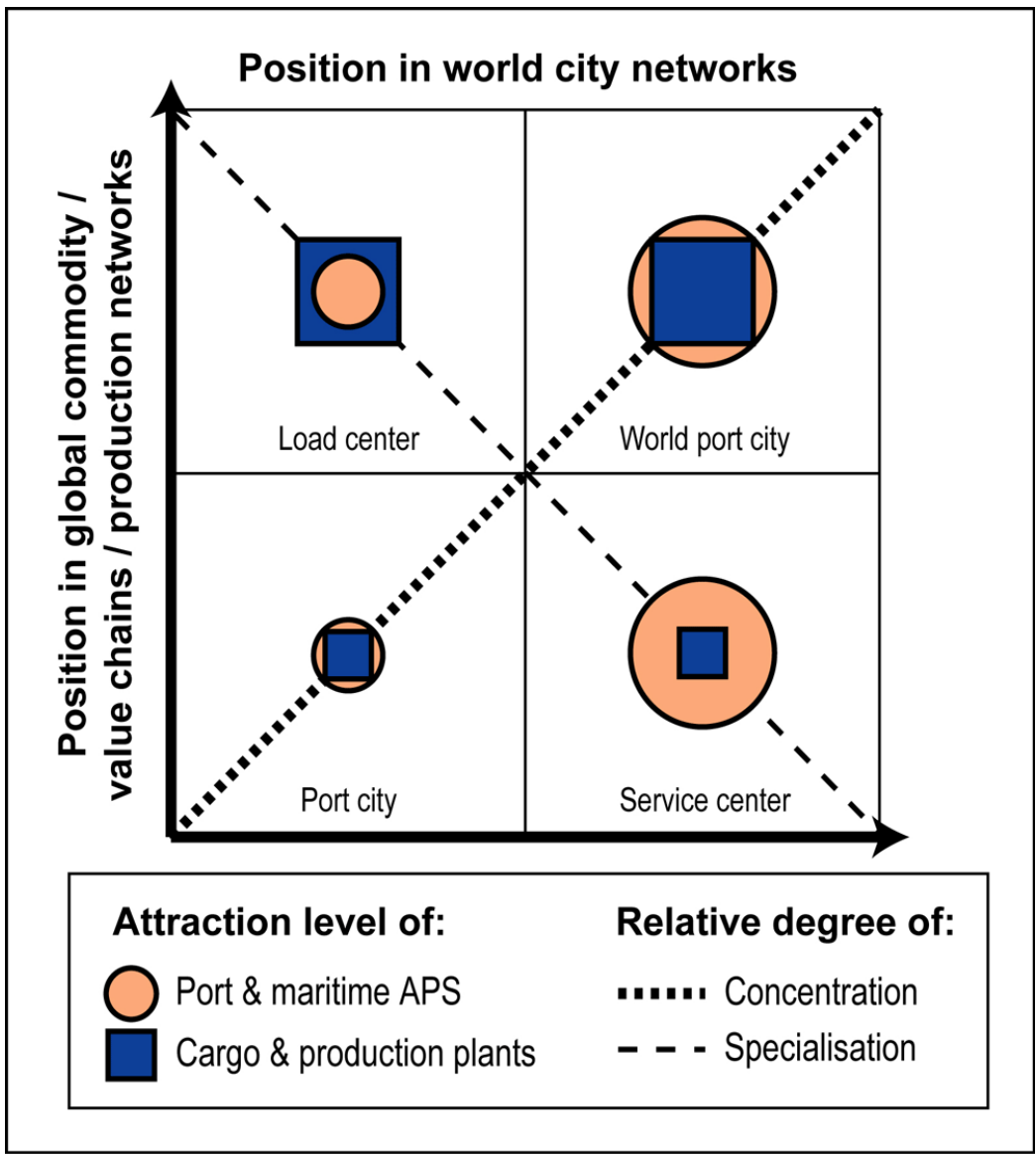


Figure 2: Global Network of $P \& I$ and maritime law offices. Source: derived from World Shipping Register 2008

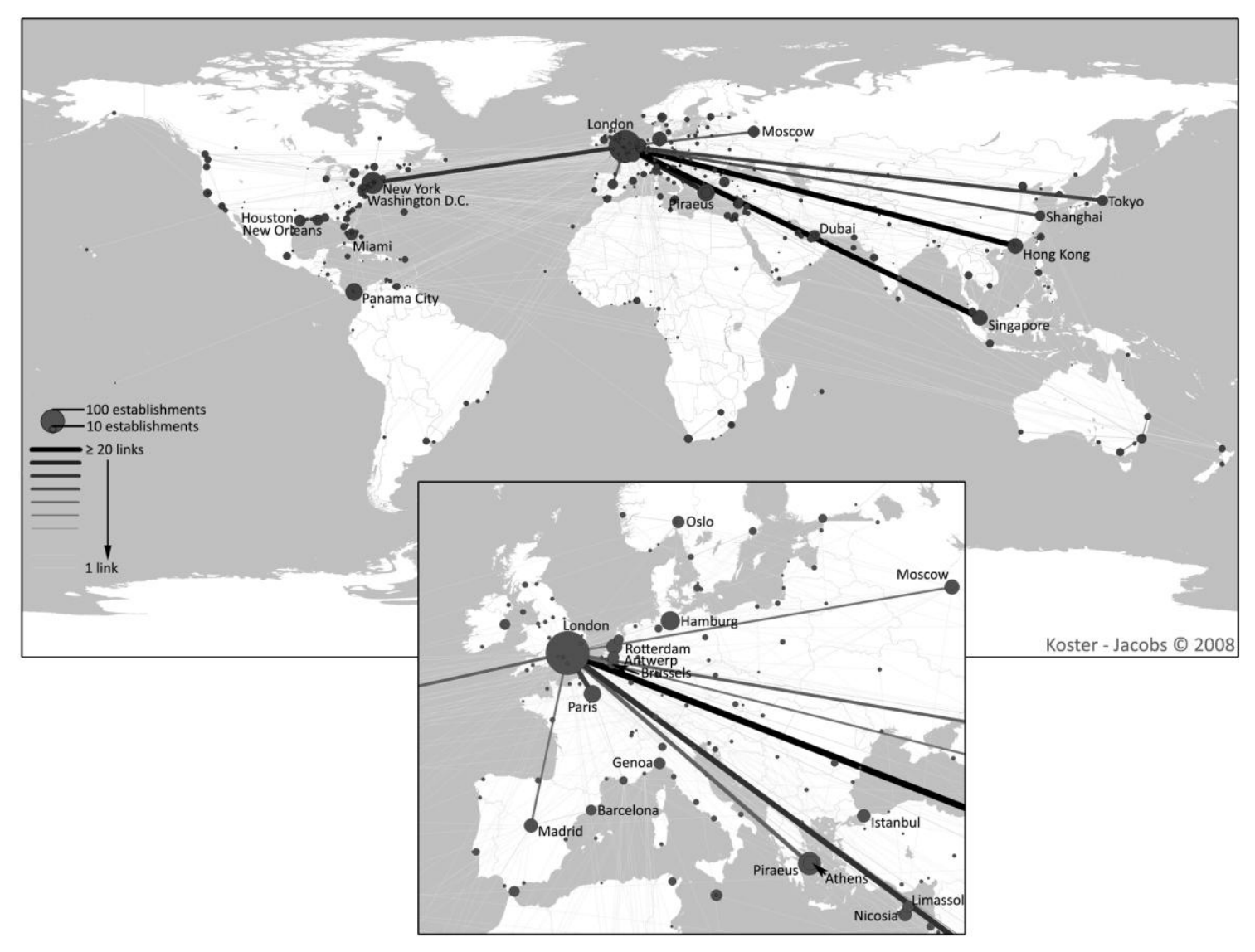


Figure 3: Graph of intra-firm links among cities connected through maritime APS (Derived from World Shipping Register, based upon TULIP software).

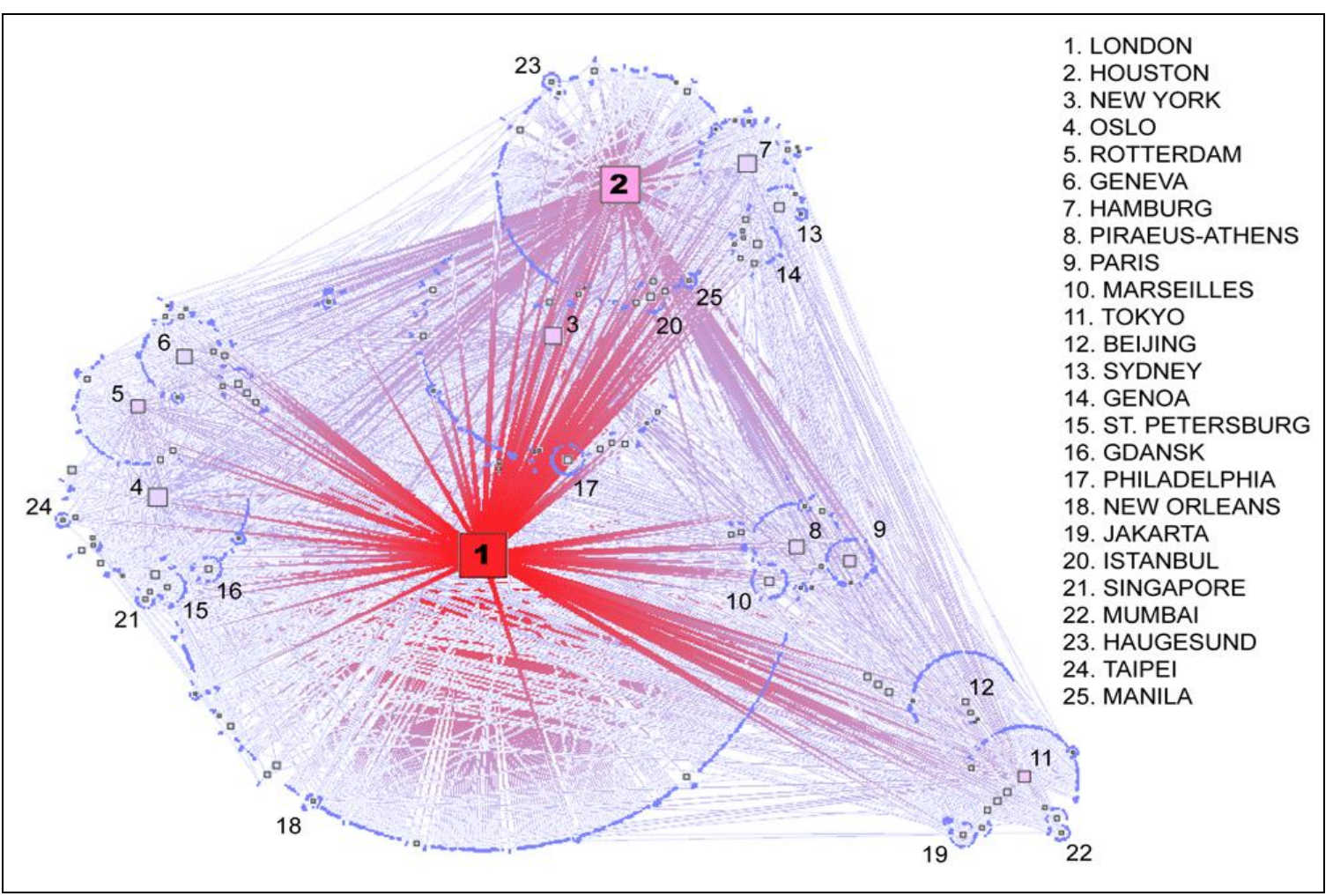


Figure 4: Port traffic volume and importance of maritime APS establishments (Sources: derived from World Shipping Register, 2008; Eurostat, 2008; AAPA, 2008; port authorities)

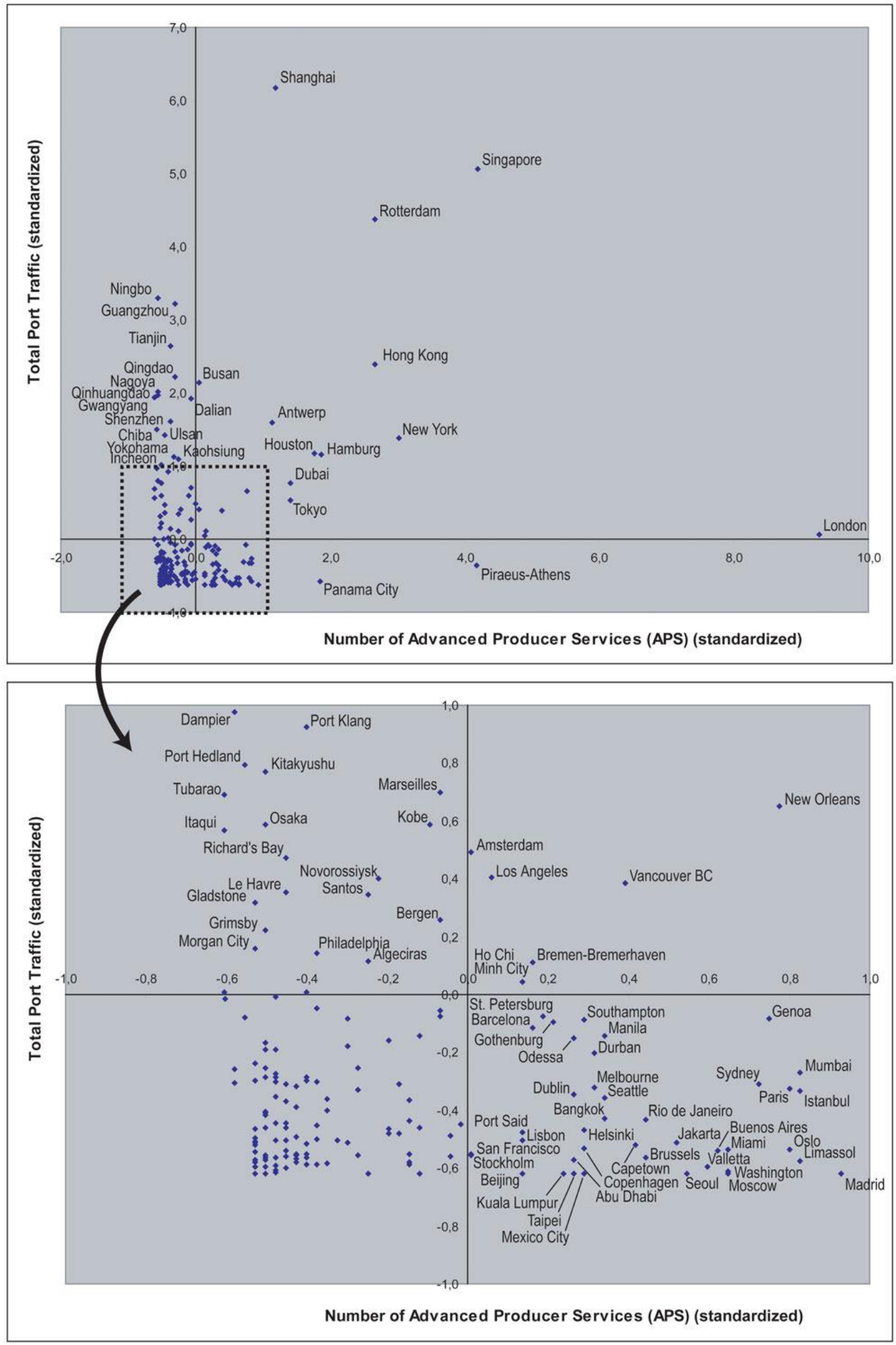


Appendix 1: Overview of World Shipping Register data

\begin{tabular}{|l|r|}
\hline \multicolumn{1}{|c|}{ Activity } & \multicolumn{1}{c|}{$\begin{array}{c}\text { Number of } \\
\text { establishments }\end{array}$} \\
\hline Bunkerer & $\mathbf{3 , 1 2 2}$ \\
\hline $\begin{array}{l}\text { Consultants, } \\
\text { surveyors }\end{array}$ & 10,738 \\
\hline Marine Equipment & $\mathbf{2 , 9 4 9}$ \\
\hline $\begin{array}{l}\text { Maritime } \\
\text { organization }\end{array}$ & 2,480 \\
\hline Other & 106,369 \\
\hline Owner, manager & $\mathbf{2 , 8 5 1}$ \\
\hline P\&I, insurance, law & 103 \\
\hline Pilotage & 5,615 \\
\hline Port agent & 3,727 \\
\hline Port authority & 5,667 \\
\hline Port service & 2,189 \\
\hline Ship broker & 836 \\
\hline Ship chandler & 8,940 \\
\hline Ship builder, repairer & 789 \\
\hline Towage, salvage & 146,749 \\
\hline TOTAL
\end{tabular}

